\title{
Seasonality and Relative Abundance of Tabanidae (Diptera) Captured on Horses in the Pantanal, Brazil
}

\author{
AntonioThadeu M Barros
}

\author{
Embrapa Pantanal, Rua 21 de Setembro 1880, 79320-900 Corumbá, MS, Brasil
}

\begin{abstract}
Once a month, from June 1992 to May 1993, collections of tabanids on horse were conducted in the Nhecolândia, Pantanal State of Mato Grosso do Sul, Brazil. Tabanid catches using hand nets were conducted from sunrise to sunset at grassland and cerradão (dense savanna) habitats. A total of 3,442 tabanids from 21 species, 12 genera, and 3 subfamilies were collected. Although species abundance varied seasonally depending on habitat, no habitat specificity was observed for the most abundant species. In the grassland, 1,625 (47.2\%) tabanids belonging to 19 species were collected, while 1,817 (52.8\%) tabanids from 17 species were caught in the cerradão. The number of tabanid species varied from 7 during winter (July/August) to 15 in the spring (October). Tabanus importunus (56\%) was the most abundant species, followed by T. occidentalis (8.2\%), and T. claripennis (8.1\%). The tabanid peak, in October, coincided with the beginning of the rainy season. The population peak of most species, including those with higher vector potential, suggests that the rainy season can be considered as the period of potentially higher risk of mechanical transmission of pathogens by tabanids to horses in the region.
\end{abstract}

Key words: tabanid - horse fly - deer fly - ecology - Pantanal - Brazil

Tabanids are known worldwide as important mechanical vectors of virus, bacteria, protozoans, and helminths, which cause diseases in wild and domestic animals (Krinsky 1976, Foil 1989). Equine diseases prevalent in the Pantanal, such as trypanosomiasis (Franke et al. 1994, Silva et al. 1995) and equine infectious anemia (Silva 1997), have their agents mechanically transmitted by tabanids (Hawkins et al. 1976, Krinsky 1976, Foil et al. 1983). Despite the fact that studies on vector ecology are essential to understand, predict, and control insect-borne diseases, relatively few studies have been conducted on tabanids in Brazil. In fact, only in the Amazon region have such ecological studies been extensively conducted (Rafael \& Charlwood 1980, Gorayeb 1993, 1999). In the Pantanal, there is a single more comprehensive study on tabanid ecology, based on trap collections (Barros \& Foil 1999).

The purpose of this study was to identify the tabanid species which attack horses in the Pantanal, as well as to determine their seasonality and relative abundance in different habitats. The present study, based on tabanid captures on horses, complements some of the information previously reported for the region (Barros \& Foil 1999).

Fax: +55-67-231.1011. E-mail: thadeu@cpap.embrapa.br Received 28 March 2001

Accepted 6 June 2001

\section{MATERIALS AND METHODS}

The study was conducted from June 1992 to May 1993 at the Nhumirim ranch (18 $59^{\prime}$ 'S, $\left.56^{\circ} 39^{\prime} \mathrm{W}\right)$, located in the Nhecolândia subregion of the Pantanal, State of Mato Grosso do Sul, Brazil (Fig. 1). The Pantanal, located in the center of South America, is about $100 \mathrm{~m}$ a.s.l. and seasonally flooded every year. Annual rainfall is about 1,000-1,200 $\mathrm{mm}$ and mean temperature and relative humidity are $24.7^{\circ} \mathrm{C}$ and $72.7 \%$, respectively. The Nhumirim ranch (about 4,374 ha) is located approximately $150 \mathrm{~km}$ east from the city of Corumbá. During the dry season (April to September) the ranch landscape is composed by a mosaic of vegetation areas (51\%) including forest, cerrado (savanna), and cerradão (dense savanna), floodable grassland areas $(24 \%)$, and ponds $(25 \%)$; from January to April flooding changes the environment (Alho et al. 1987). More detailed information on the region can be found in Ratter at al. (1988) and Alho et al. (1987).

Once a month, tabanid collection on a horse was conducted continually from sunrise to sunset, at both habitats, by two observers with the aid of hand nets $(22 \mathrm{~cm}$ diameter and $40 \mathrm{~cm}$ deep, $75 \mathrm{~cm}$ handle length). Tabanids (mostly deer flies) that landed on the head of the animal were carefully captured with plastic bags (whirl packs). The same horse (female, 8-9 years old, dark-brown color) was used along the study. Observers remained near (1 to $3 \mathrm{~m}$ ) the animal at all times and captured all flies landing on the horse. The flies were immediately killed in ethyl-acetate bottles. 


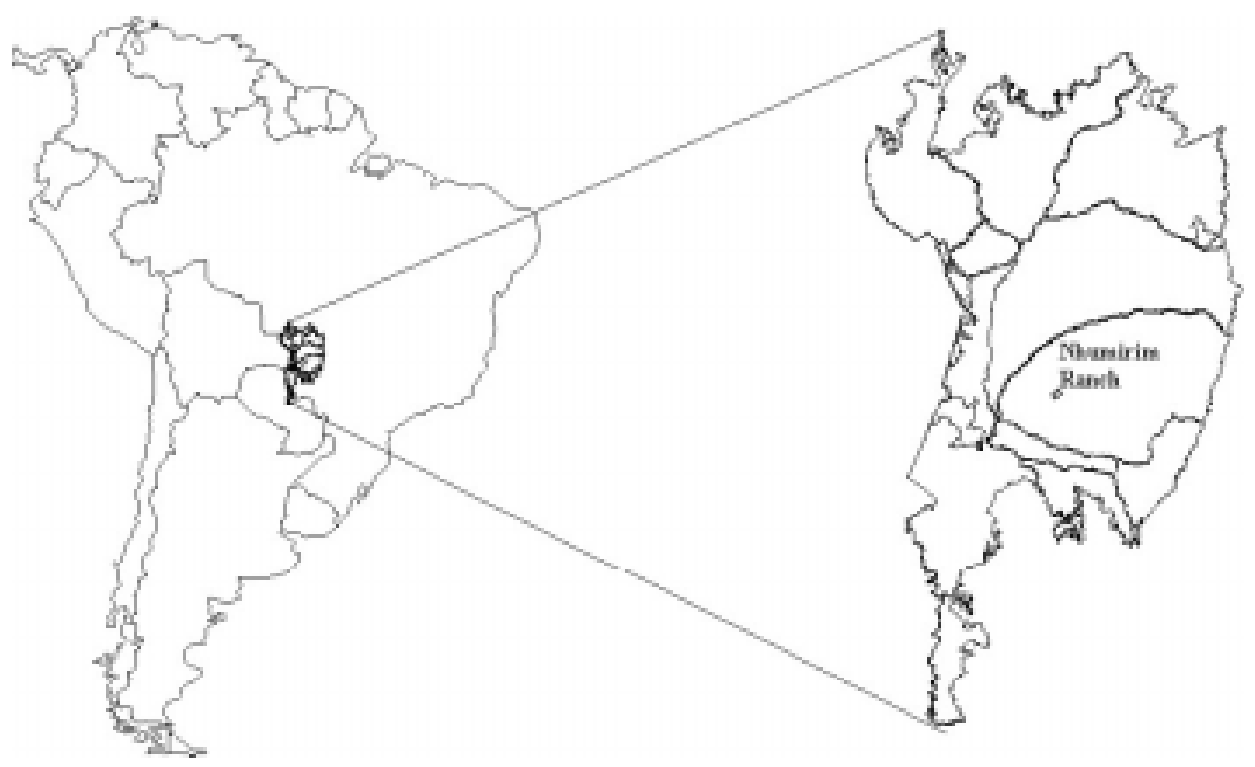

Fig. 1: location of the Nhumirim ranch (study site) in the Pantanal region, MS, Brazil

Captures were conducted on two different days in two sites, about $2 \mathrm{~km}$ apart. The sites were in different habitats: grassland - horse placed in an open area, at 5-10 $\mathrm{m}$ from the edge of a cerrado patch, and cerradão - horse placed approximately $50 \mathrm{~m}$ into a wooded area. In the case of rain, the collections were conducted on the subsequent day. The horse remained stationary, except for a 5-min walk every $30 \mathrm{~min}$ in a pre-defined transect (about $100 \mathrm{~m}$ ) along each habitat. The purpose of the walk was to increase host attractivity and improve capturing, particularly of deer flies.

At the end of each monthly capture, flies were transported to the laboratory (Embrapa Pantanal) at Corumbá for identification and enumeration. Identification of collected tabanids was made with the aid of taxonomic keys (Fairchild 1969, 1984, Wilkerson 1979, Barros \& Gorayeb 1996) and confirmation of the identification was made by Drs GB Fairchild and IS Gorayeb. Tabanus occidentalis varieties were not differentiated in this study. Specimens were incorporated into the entomological collection of the laboratory.

Data for temperature, relative humidity, and rainfall were obtained from a weather station located in the ranch.

\section{RESULTS}

In general, temperature and relative humidity can be considered as typical for the region (Fig. 2). Temperature averaged $24.5^{\circ} \mathrm{C}\left(18.4-27.5^{\circ} \mathrm{C}\right)$ throughout the year and was higher in the October-March (spring/summer) period and lower in
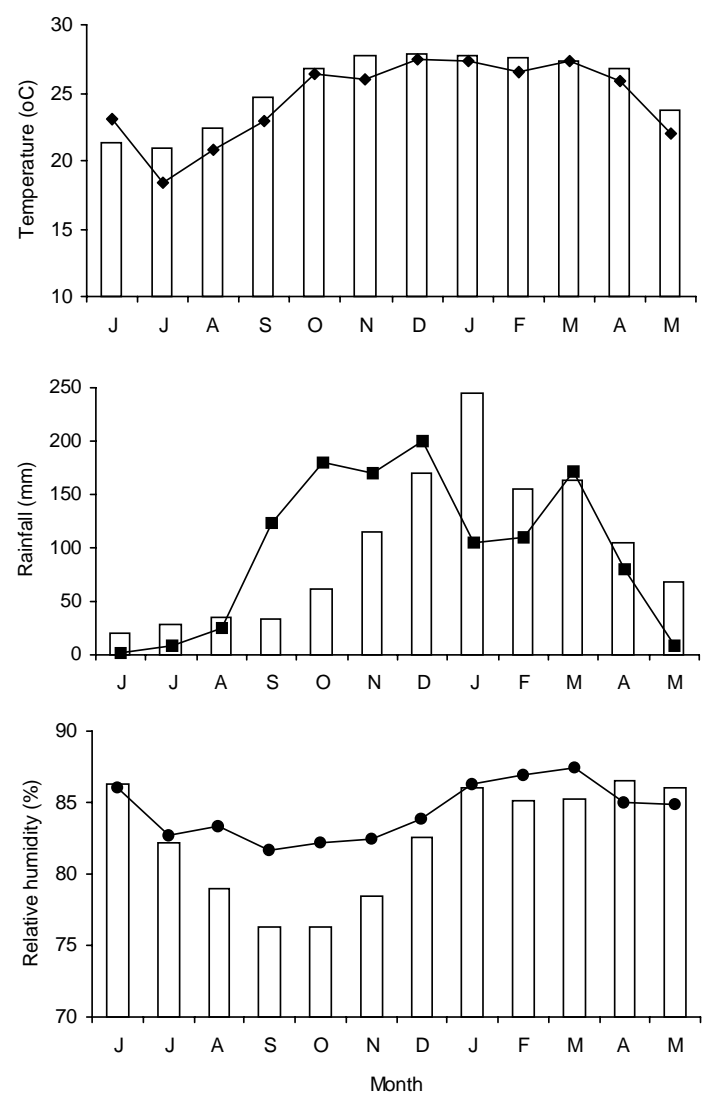

$\square$ 10-year average (1982/91) - Temp and rainfall, 5-year average (1987/91) - RH $\rightarrow$ Study period

Fig. 2: climatic data from June 1992 to May 1993 at Nhumirim ranch, Nhecolândia subregion, Pantanal, MS, Brazil 
fall/winter months (May-August). Mean relative humidity showed low variation among months, ranging from 81.7 to $87.5 \%$. The rainy season went from September to April and total yearly rainfall was $1,182.2 \mathrm{~mm}$. Except for the earlier beginning, a similar trend was observed between rainfall data during the study period and a 10-year average (Fig. 2).

A total of 3,442 tabanids, belonging to 21 species in 12 genera were collected during the 1-year study (Table I). Two previously unidentified species, one Chrysops and a Tabanus (undescribed species; I Gorayeb, in press) were collected. $\mathrm{Ta}$ banus was the most represented genus with 10 species and 2,770 individuals. The number of tabanid species collected monthly ranged from 7 (July and August) to 15 (October). Similar numbers of species and flies were observed in both open and wooded habitats; in the grassland, 1,625 (47.2\%) tabanids belonging to 19 species were collected, while $1,817(52.8 \%)$ tabanids belonging to 17 species occurred in the cerradão (Table II).

Thirteen species had relative abundance lower than $1 \%$, which combined represented only $3.5 \%$ of the total catch (Table I). However, the number of individuals belonging to the three most abundant species represented as much as $72.3 \%$ of the total of collected tabanids.

The most abundant species were T. importunus Wied. (56\%), T. occidentalis (L.) (8.2\%), T. claripennis (Bigot) (8.1\%), and Lepiselaga crassipes (Fab.) (7.7\%). Excluding species with a lower sample size $(\mathrm{n}<10)$, the 13 most abundant species were collected in both habitats (Fig. 3). T. importunus was more abundant in the grassland than in the cerradão. $T$. occidentalis and T. claripennis were more abundant in the wooded habitat, while L. crassipes showed a similar abundance in both habitats. Of the less abundant species $(\mathrm{n}<10)$, Esenbeckia lemniscata Enderlein, Phaeotabanus cajennensis (Fab.), T. pungens Wied., and T. wokei Fairchild were found exclusively in the open habitat, while Dichelacera scutellata Williston and $T$. nebulosus De Geer were caught only in the wooded habitat. As a general trend, more tabanids were collected in grassland during summer months and higher number of flies was caught in the cerradão during the winter season.

\section{TABLE I}

Seasonal distribution and relative abundance (RA) of tabanids captured on horse, from June 1992 to May 1993, in the Nhecolândia subregion, Pantanal, MS, Brazil

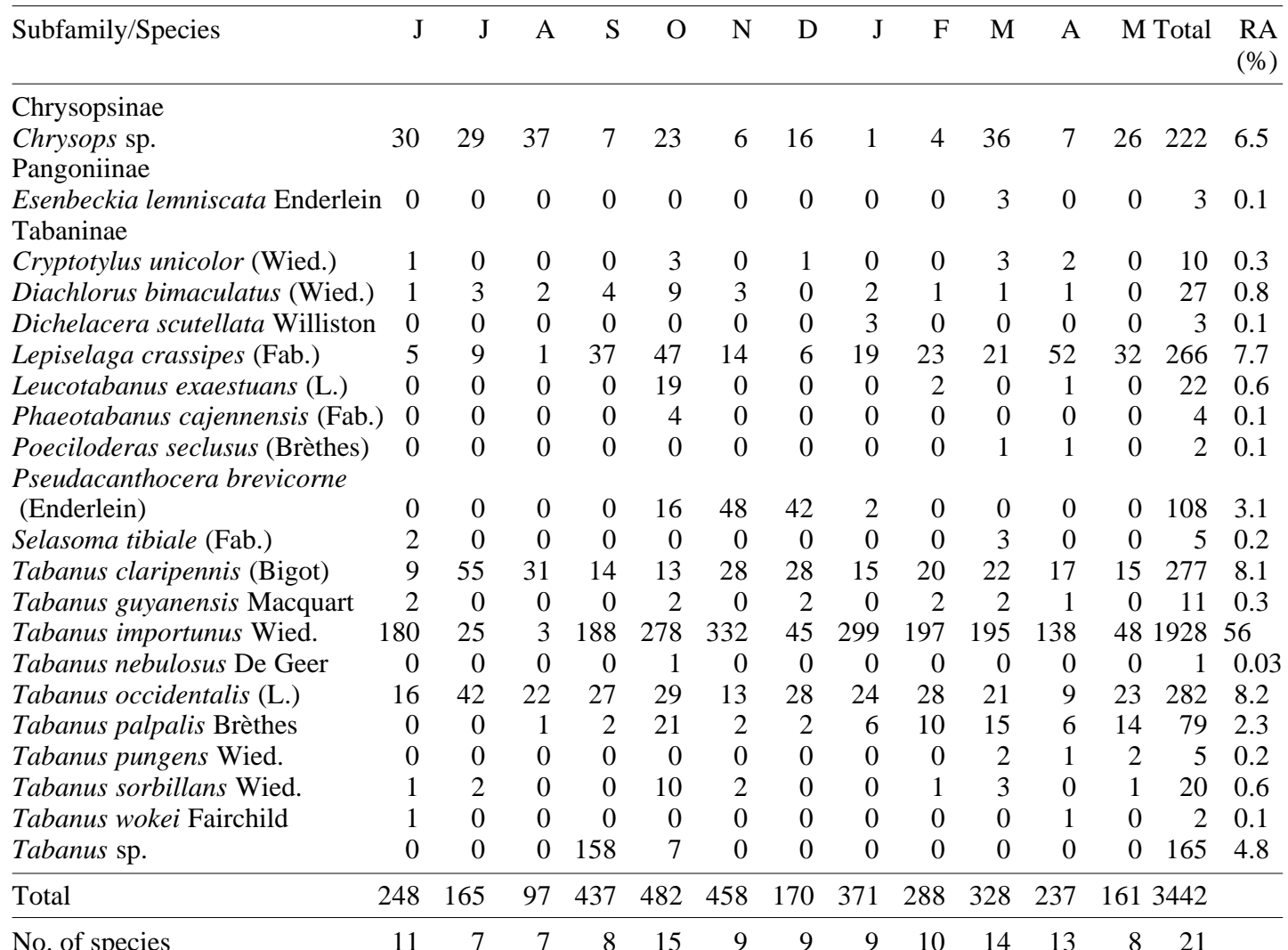


TABLE II

Seasonal occurrence and relative abundance (RA) of tabanids captured on horse, from June 1992 to May 1993, in two habitats in the Nhecolândia subregion, Pantanal, MS, Brazil

\begin{tabular}{|c|c|c|c|c|c|c|c|c|c|c|c|c|c|c|}
\hline Grassland & $\mathrm{J}$ & $\mathrm{J}$ & A & $S$ & $\mathrm{O}$ & $\mathrm{N}$ & D & $\mathbf{J}$ & $\mathrm{F}$ & M & A & M & Total & $\mathrm{RA}(\%)$ \\
\hline Chrysops sp. & 25 & 15 & 8 & 2 & 4 & 2 & 5 & 1 & 4 & 23 & 4 & 3 & 96 & 5.9 \\
\hline Cryptotylus unicolor & 0 & 0 & 0 & 0 & 0 & 0 & 0 & 0 & 0 & 3 & 2 & 0 & 5 & 0.3 \\
\hline Diachlorus bimaculatus & 1 & 1 & 1 & 2 & 5 & 0 & 0 & 2 & 1 & 0 & 1 & 0 & 14 & 0.9 \\
\hline Esenbeckia lemniscata & 0 & 0 & 0 & 0 & 0 & 0 & 0 & 0 & 0 & 3 & 0 & 0 & 3 & 0.2 \\
\hline Lepiselaga crassipes & 3 & 2 & 0 & 8 & 12 & 8 & 2 & 6 & 16 & 18 & 22 & 32 & 129 & 7.9 \\
\hline Leucotabanus exaestuans & 0 & 0 & 0 & 0 & 0 & 0 & 0 & 0 & 1 & 0 & 0 & 0 & 1 & 0.1 \\
\hline Phaeotabanus cajennensis & 0 & 0 & 0 & 0 & 4 & 0 & 0 & 0 & 0 & 0 & 0 & 0 & 4 & 0.3 \\
\hline Poeciloderas seclusus & 0 & 0 & 0 & 0 & 0 & 0 & 0 & 0 & 0 & 1 & 0 & 0 & 1 & 0.1 \\
\hline Pseudacanthocera brevicorne & e 0 & 0 & 0 & 0 & 0 & 23 & 26 & 1 & 0 & 0 & 0 & 0 & 50 & 3.1 \\
\hline Selasoma tibiale & 2 & 0 & 0 & 0 & 0 & 0 & 0 & 0 & 0 & 2 & 0 & 0 & 4 & 0.3 \\
\hline Tabanus claripennis & 6 & 12 & 1 & 2 & 0 & 19 & 9 & 5 & 7 & 21 & 12 & 13 & 107 & 6.6 \\
\hline Tabanus guyanensis & 1 & 0 & 0 & 0 & 2 & 0 & 2 & 0 & 0 & 2 & 1 & 0 & 8 & 0.5 \\
\hline Tabanus importunus & 79 & 5 & 0 & 54 & 135 & 235 & 23 & 169 & 77 & 180 & 104 & 20 & 1,081 & 66.5 \\
\hline Tabanus occidentalis & 13 & 4 & 2 & 1 & 5 & 5 & 8 & 9 & 3 & 11 & 6 & 3 & 70 & 4.3 \\
\hline Tabanus palpalis & 0 & 0 & 0 & 1 & 5 & 2 & 0 & 1 & 1 & 5 & 4 & 4 & 23 & 1.4 \\
\hline Tabanus pungens & 0 & 0 & 0 & 0 & 0 & 0 & 0 & 0 & 0 & 2 & 1 & 2 & 5 & 0.3 \\
\hline Tabanus sorbillans & 0 & 0 & 0 & 0 & 0 & 1 & 0 & 0 & 0 & 0 & 0 & 0 & 1 & 0.1 \\
\hline Tabanus wokei & 1 & 0 & 0 & 0 & 0 & 0 & 0 & 0 & 0 & 0 & 1 & 0 & 2 & 0.1 \\
\hline Tabanus sp. & 0 & 0 & 0 & 19 & 2 & 0 & 0 & 0 & 0 & 0 & 0 & 0 & 21 & 1.3 \\
\hline Total & 131 & 39 & 12 & 89 & 174 & 295 & 75 & 194 & 110 & 271 & 158 & 77 & 1,625 & \\
\hline
\end{tabular}

Cerradão

\begin{tabular}{lrrrrrrrrrrrrrr}
\hline Chrysops sp. & 5 & 14 & 29 & 5 & 19 & 4 & 11 & 0 & 0 & 13 & 3 & 23 & 126 & 6.9 \\
Cryptotylus unicolor & 1 & 0 & 0 & 0 & 3 & 0 & 1 & 0 & 0 & 0 & 0 & 0 & 5 & 0.3 \\
Diachlorus bimaculatus & 0 & 2 & 1 & 2 & 4 & 3 & 0 & 0 & 0 & 1 & 0 & 0 & 13 & 0.7 \\
Dichelacera scutellata & 0 & 0 & 0 & 0 & 0 & 0 & 0 & 3 & 0 & 0 & 0 & 0 & 3 & 0.2 \\
Lepiselaga crassipes & 2 & 7 & 1 & 29 & 35 & 6 & 4 & 13 & 7 & 3 & 30 & 0 & 137 & 7.5 \\
Leucotabanus exaestuans & 0 & 0 & 0 & 0 & 19 & 0 & 0 & 0 & 1 & 0 & 1 & 0 & 21 & 1.2 \\
Poeciloderas seclusus & 0 & 0 & 0 & 0 & 0 & 0 & 0 & 0 & 0 & 0 & 1 & 0 & 1 & 0.1 \\
Pseudacanthocera brevicorne & 0 & 0 & 0 & 0 & 16 & 25 & 16 & 1 & 0 & 0 & 0 & 0 & 58 & 3.2 \\
Selasoma tibiale & 0 & 0 & 0 & 0 & 0 & 0 & 0 & 0 & 0 & 1 & 0 & 0 & 1 & 0.1 \\
Tabanus claripennis & 3 & 43 & 30 & 12 & 13 & 19 & 19 & 10 & 13 & 1 & 5 & 2 & 170 & 9.4 \\
Tabanus guyanensis & 1 & 0 & 0 & 0 & 0 & 0 & 0 & 0 & 2 & 0 & 0 & 0 & 3 & 0.2 \\
Tabanus importunus & 101 & 20 & 3 & 134 & 143 & 97 & 22 & 130 & 120 & 15 & 34 & 28 & 847 & 46.6 \\
Tabanus nebulosus & 0 & 0 & 0 & 0 & 1 & 0 & 0 & 0 & 0 & 0 & 0 & 0 & 1 & 0.1 \\
Tabanus occidentalis & 3 & 38 & 20 & 26 & 24 & 8 & 20 & 15 & 25 & 10 & 3 & 20 & 212 & 11.7 \\
Tabanus palpalis & 0 & 0 & 1 & 1 & 16 & 0 & 2 & 5 & 9 & 10 & 2 & 10 & 56 & 3.1 \\
Tabanus sorbillans & 1 & 2 & 0 & 0 & 10 & 1 & 0 & 0 & 1 & 3 & 0 & 1 & 19 & 1.1 \\
Tabanus sp. & 0 & 0 & 0 & 139 & 5 & 0 & 0 & 0 & 0 & 0 & 0 & 0 & 144 & 7.9 \\
\hline Total & 117 & 126 & 85 & 348 & 308 & 163 & 95 & 177 & 178 & 57 & 79 & 84 & 1,817 & \\
\hline
\end{tabular}

In general, the tabanid population increased in September, coinciding with the beginning of the rainy season (Table I, Fig. 2). The population peak occurred in October, and gradually declined until reaching its lowest levels at the end of the dry season. Seasonal fluctuation was somewhat different among populations of the most abundant species. L. crassipes showed two peaks, about the beginning and at the end of the rainy season, while $T$. importunus peaked after the rainy season had began. T. occidentalis and T. claripennis were more abundant during the dry season.

\section{DISCUSSION}

The total number of tabanids caught on horses in this study (3,442 individuals) was much higher than the captured with canopy traps (944 flies) baited with octenol (artificial attractant) conducted in the same area and habitats, during the same period (Barros \& Foil 1999). Furthermore, monthly collections in each habitat were conducted in a single day period in this study and over a ten-day period in traps (Barros \& Foil 1999). The results clearly express the difference between the use of traps and a natural host for tabanid sampling. How- 


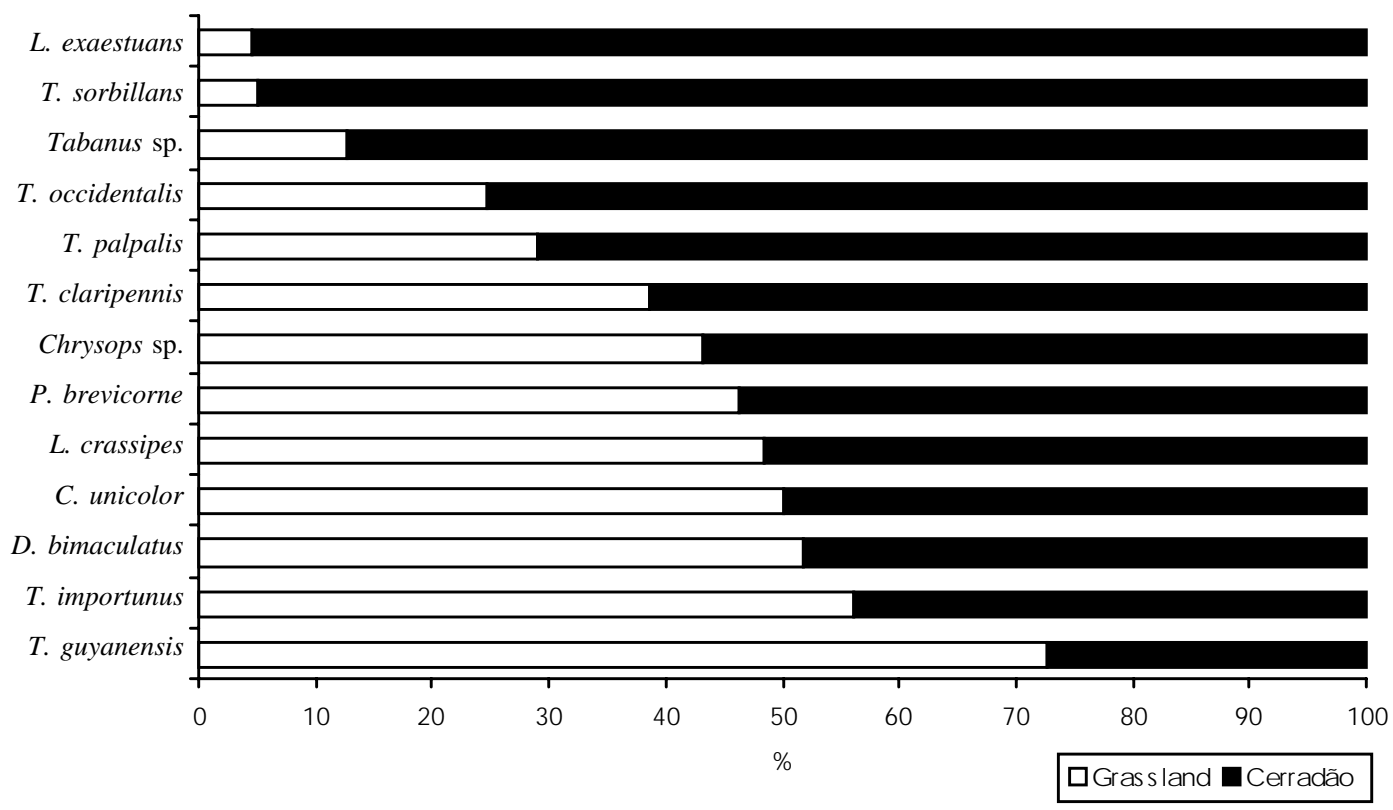

Fig. 3: frequency of tabanid species (n > 10) captured on horse, in two habitats, from June 1992 to May 1993, in the Nhecolândia subregion, Pantanal, MS, Brazil; L: Leucotabanus; T: Tabanus; P: Pseudacanthocera; C: Cryptotylus; D: Diachlorus

ever, the number of species was very similar for both methods and most species collected by traps were also caught on horses. Only two species, $E$. lemniscata and T. guyanensis, were not collected in traps.

The number of species collected was higher than previously reported from collections on horses in northern Argentina (Hack 1970) but lower than found in the southeast (Bouvier 1952) and northern (Gorayeb 1993) regions of Brazil. In this study, most species (61.9\%) showed relative abundance lower than $1 \%$, which is similar to the $53.2 \%$ previously reported for the region (Barros \& Foil 1999), based on trap collections. Also, similar results from tabanid captures on horses were obtained by Bouvier (1952), who found $65.9 \%$ of the species with low $(<1 \%)$ relative abundance. Actually, relatively high percentages (ranging between 40 and $80 \%$ ) of low abundance species have been commonly reported from studies using several techniques and conducted under different conditions and places, such as Argentina (Hack 1970), Brazil (Gorayeb 1993), Panama (Fairchild 1942), USA (Burnett \& Hays 1977), and Canada (Smith et al. 1970).

The three most abundant species, T. importunus, $T$. occidentalis, and $T$. claripennis, represented as much as $72.3 \%$ of the total catch. Barros and Foil (1999) found that $67.2 \%$ of the total collection was represented by the same species. Al- though the relative abundance of $T$. importunus was much higher on horses (56\%) than in traps (29.5\%), the relative abundance of $T$. occidentalis $(8.2 \%)$ and $T$. claripennis $(8.1 \%$ ) increased to $25.4 \%$ and $12.3 \%$ in traps, respectively (Barros \& Foil 1999). Also, $T$. dorsiger $(=T$. occidentalis $)$ and $T$. importunus were some of the most abundant species captured on horses in the Central Amazon (Rafael \& Charlwood 1980).

In the present study, T. importunus represented as much as $72.5 \%$ of the total catch during its peak. However, this species showed a markedly lower (less than $0.2 \%$ ) relative abundance in studies conducted elsewhere in Brazil (Bouvier 1952, Gorayeb 1993). The relatively high abundance of $T$. importunus in the Pantanal (Barros \& Foil 1999, this study), associated with its high potential of transmission due to its anautogenous reproduction, higher survival index (longevity), and higher number of gonotrophic cycles (Rafael \& Charlwood 1980), as well as host stressing and interrupted feeding behavior (Barros 2000), strongly suggests that $T$. importunus could play an important role as a mechanic vector of pathogens for equine hosts in the region.

The general peak of tabanids observed about the beginning of the rainy season coincided with previous records for most species in the Pantanal (Barros \& Foil 1999) and in São Paulo (Bouvier 1952). Also, the higher number of tabanid species 
near the beginning and the end of the rainy period was similar to that reported for the Oriental Amazon (Gorayeb 1993). The high abundance of most tabanid species during the rainy season, particularly those potentially important as mechanical vectors (such as T. importunus), may explain the outbreaks of equine trypanosomosis (Trypanosoma evansi) as well as the temporal variation of T. evansi seroprevalence in equines previously reported in the Pantanal (Silva et al. 1995, Dávila et al. 1999).

A seasonal sucession of the most abundant species was observed and may be associated with a strategy to reduce interspecific competition (Rafael 1982). Thus, T. claripennis and T. occidentalis peaked during the dry season (July), while $L$. crassipes peaked after the beginning (October) and at the end (April) of the rainy season. T. importunus peaked some time after the rainy season had began (November) but was generally abundant during the whole rainy season (from September to April). In Central Amazon, a population peak of T. importunus was observed in October, before the official rainy season but after some rainfall had began (Rafael \& Charlwood 1980). In northern Argentina, $T$. claripennis was relatively abundant from April to June (below $20^{\circ} \mathrm{C}$ ), although an isolated peak was observed in November (Hack 1970).

A similar number of tabanid species and individuals were caught in both sampled habitats, although a target host tends to be attractive in a wider range (because both visual and olfactive attractiveness) in an open than in a wooded habitat. Barros and Foil (1999) suggested that seasonal fluctuations in habitat use by tabanids as well as their lack of habitat specificity may have contributed to this finding. Also, no habitat specificity was showed in the present study by the most representative species ( $>5$ individuals sampled), since all those species were caught in both open and wooded habitats. However, it should be stressed that collections in the open habitat were actually conducted near a wood edge, which surely influenced the results. Thus, results from habitat collections are discussed as habitat abundance or use but not related to habitat preference.

Tabanid abundance related to the habitat showed a seasonal change during the year. When temperature conditions were more adverse during winter (July-August), a higher number of tabanids were caught in the wooded habitat than in grassland. A similar situation was previously observed from canopy trap collections (Barros \& Foil 1999). General trends of the most abundant species regarding their habitat abundance were also similar for these two studies, with a higher abundance of $T$. importunus in grassland, while T. occidentalis and $T$. claripennis were more abundant in the wooded habitat. As observed in the Pantanal, T. importunus also was more abundant in the open habitat in the Amazon (Gorayeb 1993).

\section{ACKNOWLEDGEMENTS}

To Drs Lane Foil (Louisiana State University) and Larry Hribar (University of Florida) for help in establishing the initial reference collection, and to Drs GB Fairchild (in memoriam) and Inocêncio S Gorayeb (Museu Emílio Goeldi) for the taxonomic classification of the material. To Wibert Avellar, Waldomiro Lima e Silva, and Geraldo $\mathrm{N}$ do Nascimento for their assistance in field activities and to Valdete Sanchez and Cecília Baracat for technical assistance. To the staff of the Nhumirim ranch for logistic support.

\section{REFERENCES}

Alho CJR, Campos ZMS, Gonçalves HC 1987. Ecologia de capivara (Hydrochaeris hydrochaeris, Rodentia) do Pantanal. I - Habitats, densidades e tamanho de grupo. Rev Bras Biol 47: 87-97.

Barros ATM 2000. Comportamento de repasto de tabanídeos (Diptera: Tabanidae) em eqüinos no Pantanal. Simpósio sobre Recursos Naturais e Sócioeconômicos do Pantanal, 3, Resumos, Embrapa CPAP, Corumbá, Mato Grosso do Sul, p.151-152.

Barros T, Foil L 1999. Seasonal occurrence and relative abundance of Tabanidae (Diptera) from the Pantanal region. Mem Entomol Internl 14: 387-396.

Barros ATM, Gorayeb IS 1996. Chave de identificação para tabanídeos (Diptera: Tabanidae) do Pantanal, sub-região da Nhecolândia, Mato Grosso do Sul, Brasil. Rev Brasil Biol 56: 547-551.

Bouvier G 1952. Notes sur les Tabanidés de la region de Campinas (Estado S. Paulo) - Brésil. Mem Inst Oswaldo Cruz 50: 581-595.

Burnett AM, Hays K 1977. Seasonal and diurnal distributions of adult female horse flies (Diptera, Tabanidae) at Gold Hill, Alabama. Agricultural Experiment Station, Auburn, University, Auburn, Circular 237, $28 \mathrm{pp}$.

Dávila AMR, Souza SS, Campos C, Silva RAMS 1999. The seroprevalence of equine trypanosomosis in the Pantanal. Mem Inst Oswaldo Cruz 94: 199-202.

Fairchild GB 1942. The seasonal distribution of some Tabanidae (Dipt.) in Panama. Ann Entomol Soc Am 35: 85-91.

Fairchild GB 1969. Notes on neotropical Tabanidae. XII. Classification and distribution, with keys to genera and subgenera. Arq Zool S Paulo 17: 199-255.

Fairchild GB 1984. Notes on Neotropical Tabanidae (Diptera) XX. The larger species of Tabanus of eastern South America. Contr Am Entom Inst 21: 1-50.

Foil LD 1989. Tabanids as vectors of disease agents. Parasitol Today 5: 88-96.

Foil LD, Meek CL, Adams WV, Issel CJ 1983. Mechanical transmission of equine infectious anemia virus by deer flies (Chrysops flavidus) and stable flies (Stomoxys calcitrans). Am J Vet Res 44: 155156.

Franke CR, Greiner M, Mehlitz D 1994. Investigations on naturally occurring Trypanosoma evansi infec- 
tions in horses, cattle, dogs and capybaras (Hydrochaeris hydrochaeris) in Pantanal de Poconé (Mato Grosso, Brazil). Acta Trop 58: 159-169.

Gorayeb IS 1993. Tabanidae (Diptera) da Amazônia. XI. Sazonalidade das espécies da Amazônia oriental e correlação com fatores climáticos. Bol Mus Para Emilio Goeldi sér Zool 9: 241-281.

Gorayeb IS 1999. Tabanidae (Diptera) of the Amazon. XIV. Vertical stratification in an eastern Amazonian forest. Mem Entomol Internl 14: 367-386.

Hack WH 1970. Datos bionomicos de tabanidos de Corrientes. Acta Zool Lilloana 27: 269-298.

Hawkins JA, Adams Jr WV, Wilson BH, Issel CJ, Roth EE 1976. Transmission of equine infectious anemia virus by Tabanus fuscicostatus. JAVMA 168: 63-64.

Krinsky WL 1976. Animal disease agents transmited by horse flies (Diptera: Tabanidae). J Med Entomol 13: 225- 275.

Rafael JA 1982. Ocorrência sazonal e abundância relativa de Tabanidae (Diptera) no Campus Universitário, Manaus, Amazonas. Acta Amazônica 12: 225-229.

Rafael JA, Charlwood JD 1980. Idade fisiológica, variação sazonal e periodicidade diurna de quatro populações de Tabanidae (Diptera) no Campus Universitário, Manaus, Brasil. Acta Amazônica 10: 907- 927.

Ratter JA, Pott A, Pott VJ, Cunha CN da, Haridasan M 1988. Observations on woody vegetation types in the Pantanal and in Corumbá, Brazil. Notes RBG Edinb 45: 503-525.

Silva RAMS 1997. Anemia infecciosa equina. In JB Catto, JRB Sereno, JA Comastri Filho (eds), Tecnologias e Informações para a Pecuária de Corte no Pantanal, Embrapa CPAP, Corumbá, p. 139-147.

Silva RAMS, Barros ATM, Herrera HM 1995. Trypanosomosis outbreaks due to Trypanosoma evansi in the Pantanal, Brazil. Revue Élev Méd Pays Trop 48: 315-319.

Smith SM, Davies DM, Golini VI 1970. A contribution to the bionomics of the Tabanidae (Diptera) of Algonquin Park, Ontario: seasonal distribution, habitat preferences, and biting records. Can Entomol 102: 1461-1473.

Wilkerson RC 1979. Horse flies (Diptera: Tabanidae) of the Colombian departments of Choco, Valle and Cauca. Cespedesia 8: 99-421. 
924 Horn Fly Seasonality in Pantanal - Antonio Thadeu M Barros 